\title{
Unsafe at Low Levels: Adopt a Federal MCL for 1,2,3-Trichloropropane in United States' Drinking Water
}

\author{
B. Hope Hauptman ${ }^{1}$, Colleen C. Naughton ${ }^{2}$ \\ ${ }^{1}$ University of California Merced, Environmental Systems Graduate Group, Merced, CA \\ ${ }^{2}$ University of California Merced, Department of Civil and Environmental Engineering, Merced, CA \\ https://doi.org/10.38126/ISPG190104 \\ Corresponding author: bhauptman@ucmerced.edu \\ Keywords: TCP; policy analysis; drinking water pollution, maximum contaminant level
}

Executive Summary: 1,2,3-trichloropropane (TCP) is a toxic, man-made chemical used widely in agricultural and other contexts from the 1940s to the 1980s. TCP has settled into the groundwater supplies nearly everywhere it was used. In 2009, the Environmental Protection Agency (EPA) included TCP on the Third Contaminant Candidate list (CCL3) and listed the safe oral reference dose (RfD) for TCP at 0.004 milligrams per kilogram per day. Since then, we have learned that the scope of the TCP contamination problem is greater than first understood. At least 13 states and one territory have contaminated wells. Animal studies show that TCP is a potent carcinogen, and toxicology studies suggest that TCP is unsafe at levels at and above its 5 ppt detection limit. Three states, California, Hawaii, and New Jersey have adopted enforceable maximum contaminant levels of TCP in groundwater. As other states become aware of contamination levels, it is likely that some of them will also regulate TCP, but that could take many years. Federal legislation could mandate EPA advisories sooner than state legislation. The EPA has used the detection limit as the maximum for at least one other chemical, 1,2-Dibromo-3-chloropropane (DBCP), a common co-contaminant of TCP. We recommend that the EPA adopt TCP's lowest detection level, 5 ppt, as the federal maximum contaminant level

\section{The Problem: Contaminated Tap Water}

For many Americans, the water they drink, cook with, and bathe in is polluted with unsafe chemicals. While the federal government has created national regulations for some chemicals such as lead and polychlorinated biphenyls (PCBs), much regulation is done state-by-state, resulting in inconsistent policies that are often administered inequitably. Those inequities become clear when we look at the communities most impacted by toxic water, including rural and marginalized communities facing other inequities, such as limited access to healthcare and other basic services (Balazs and Ray 2014; Schaider et al. 2019).
Inconsistency in the regulation of harmful chemical pollutants results in limits that are either set too high or lacking all-together. The history of 1,2,3-Trichloropropane (TCP) makes clear the potential consequences of this type of regulation, or lack thereof. Some states including California, Hawaii, and New Jersey have set MCLs for TCP at 5, 600, and $30 \mathrm{ng} / \mathrm{L}$, respectively (U.S. EPA 2017a; Torralba-Sanchez et al. 2020). The MCL of these three states differ by up to two orders of magnitude and illustrate the need for a national regulation so that all consumers are protected at the same risk level. 
Used as an industrial solvent, injected into the soil, and included as a component in widely used pesticides, TCP had been spreading for years before the scientific community recognized its deleterious effects. As a result, people, often in marginalized communities and rural agricultural outposts, had been drinking water contaminated with TCP long before Hawaii, California, and New Jersey set state maximum contaminant levels (MCL) and required that water systems are regularly monitored to detect its presence.

Once thought of as an emerging contaminant, TCP is now understood to be carcinogenic and because it is ubiquitous in groundwater near agricultural regions, this issue demands federal oversight (Kielhorn et al. 2003; Burow et al. 2019). A World Bank report "Quality Unknown," identified fragmented regulations across countries and agencies as a cause for uncertainty, and a hindrance to progress toward universal clean and accessible drinking water (Damania et al. 2019). TCP meets all the statutory criteria that the EPA uses when it considers whether to regulate a chemical, as required by The Safe Drinking Water Act (U.S. SDWA 1996; U.S. EPA n.d.):

- TCP is a recognized carcinogen with adverse health effects (Kielhorn et al. 2003),

- TCP occurs in public water systems in at least thirteen states and one U.S. territory,

- Federally regulating TCP would be a "meaningful opportunity" to reduce health risk for consumers especially in marginalized rural agricultural communities.

\section{i. Uses and prevalence TCP}

TCP is a chlorinated organic pollutant that contaminated drinking water in areas where it was applied. Since it does not readily bind to soil and is highly stable, TCP has leached into groundwater and persists (US EPA 2017a). In 1970, the California Department of Food and Agriculture began listing fumigants with TCP in pesticide use reports, ultimately connecting TCP to more than forty crop types (CDFA 1970-1984).

Because TCP is on the third Candidate Contaminant List 3 (CCL3), it is part of the EPA's third Unregulated Contaminant Monitoring Rule (UCMR) which assesses the breadth of population exposure levels. For twelve months between 2013-2015, the EPA program sampled all public water systems serving more than 10,000 people and 800 representative systems serving 10,000 or fewer people (U.S. EPA 2012; U.S. EPA 2017b). The data showed that TCP was present in groundwater at levels above the California's Public Health Goal (0.007 ppt) in Alabama, Arizona, California, Connecticut, Florida, Hawaii, Maryland, North Carolina, New Jersey, New Mexico, New York, Pennsylvania, Puerto Rico, and Virginia (U.S. EPA 2017c) (Figure 1).

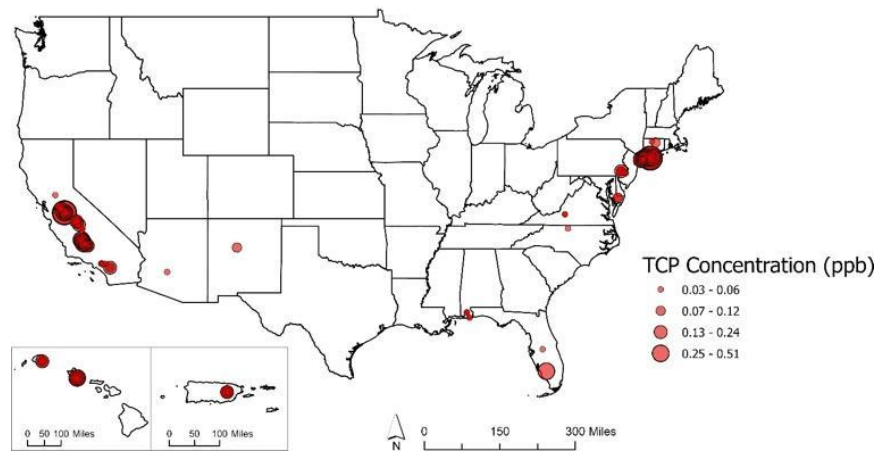

Figure 1: Map showing U.S. locations which have detected 1,2,3-Trichloropropane (TCP) levels in groundwater. Hawaii (left) and Puerto Rico (right) are in the inset. TCP concentration in parts per billion (ppb) or $\mu \mathrm{g} / \mathrm{L}$. Data from EPA, (UCMR, 2013-2015).

\section{ii. Harmful effects of TCP exposure}

As early as 1985 evidence began to show TCP's potent mutagenic properties in mice and rats when delivered orally or via inhalation (Villeneuve et al. 1985). In 1993, the U.S. National Toxicology Program (NTP) two-year chronic toxicity study showed "clear evidence of carcinogenic activity" in both male and female rats (NTP 1993). Although toxicity studies focus on TCP's carcinogenic potential, studies from both the World Health Organization and the EPA indicated that ingesting TCP can significantly reduce fertility and reproduction in mice (Keilhorn et al. 2003; U.S. EPA 2009).

On the heels of the NTP study, Irwin et al. (1995) published the first peer reviewed academic study of TCP's carcinogenic potential. They chose their dose range to mimic human occupational exposure based on the Occupational Safety and Health Administration (OSHA) limit: $10 \mathrm{ppm}$ for an 8-hr. 
workday. The study showed that TCP induced a carcinogenic response even at the lowest doses (3 $\mathrm{mg} / \mathrm{kg}$ for rats and $6 \mathrm{mg} / \mathrm{kg}$ for mice). Irwin et al. (1995) theorized that, given the high levels of mutagenic activity in the low dose groups, even smaller amounts of TCP would have induced cellular changes.

La et al. (1996) discovered that when TCP was delivered orally to mice and rats, tumors developed in multiple sites including the liver, stomach, and kidneys. The incidence of TCP-induced forestomach tumors was nearly $100 \%$, even among the low-dose group ( $3 \mathrm{mg} / \mathrm{kg}$ for five days in mice and $6 \mathrm{mg} / \mathrm{kg}$ for five days in rats), when delivered orally via oil suspension. Although more information is needed regarding prolonged exposure in humans, La et al. (1996)'s findings confirm that TCP is carcinogenic even at the typical low doses found in tap water.

In the most recent study of TCP toxicology, Tardff et al. (2010) used a biological risk assessment approach to estimate Drinking Water Equivalent Levels (DWELs) for a lifetime of consumption. Tardff et al. (2010) used an internationally recognized framework from the World Health Organization and the EPA to estimate, from animal models, safe TCP exposure levels for humans over a lifetime. They concluded that to protect against non-cancer toxicity and cancer, tap water can be consumed safely at TCP concentrations up to $200 \mathrm{ppb}$ or micrograms per liter; however, the EPA's Integrated Risk Information System (IRIS) lists chronic oral reference dose (RfD) of $4 \times 10^{-3}$ milligrams per kilogram per day (mg/kg/day). A RfD estimates the amount of a substance a person can be exposed to without adverse health effects over a lifetime of daily exposure (U.S. EPA n.d.). For comparison, a $62 \mathrm{~kg}$ person (average human weight) drinking 3 liters of water a day of water contaminated with $200 \mathrm{ppb}$ would be equivalent to a comparable level of approximately $0.01 \mathrm{mg} / \mathrm{kg} /$ day or almost 2.5 times the EPA's RfD (Walpole et al. 2012).

\section{iii. Clean-up and co-contamination}

Removing TCP from drinking water is costly. Del Rey, California - a small unincorporated rural community would have to install four filtration units to remove all of the TCP from their groundwater supplies at a total estimated cost of more than $\$ 18$ million dollars (Klein, 2018). The Best Available Technology (BAT) is to pump and then treat contaminated water by passing it through Granular Activated Carbon (GAC). However, the carbon source must be replaced relatively often since GAC has a low affinity for TCP (Hauptman and Naughton 2021). TCP is a common co-contaminant with 1,2-Dibromo-3-chloropropane (DBCP), which is also treated with GAC (Burow et al. 2019). Like TCP, DBCP is another legacy contaminant no longer used but persistent in the environment due to its long half-life and low natural attenuation. Also a soil fumigant, DBCP is carcinogenic and can cause serious declines in male fertility including sterility (Teitelbaum 1999). The federal MCL for DBCP was set in 1991 at 0.2 ppb (U.S. EPA 2002).

\section{Stakeholders}

The EPA administrator, EPA scientists and decision makers, and members of the U.S. Senate Committee on Environment and Public Works should work together to advance TCP from the CCL stage to a federal MCL. Those living in or near agricultural areas are the most at risk of drinking water contaminated with TCP from non-point source contamination (Burow et al. 2019). There are also some communities near point source contamination from industrial use. For example, groundwater in southern California's San Fernando Valley superfund site called the Burbank Operable Unit has levels of TCP above the California MCL due to decades of aerospace manufacturing (Book and Spath 2007).

California's impacted cities are funding clean-up with money from legal settlements rather than passing costs off to consumers. In 2011 Livingston, California settled a lawsuit for 9 million dollars against two chemical companies to fund TCP clean-up efforts (North 2011). After a four-month trial in 2019, the City of Atwater, California was awarded $\$ 63$ million to treat TCP contaminated groundwater after suing Shell Oil Co (Schlesinger 2019). A federal MCL would remove uncertainty about TCP safety and any doubts that it must be removed from the drinking water supply. Chemical 
companies that marketed fumigants containing TCP to farmers may wish to avoid costly litigation and might oppose a federal MCL for this very reason.

\section{Regulatory Background}

The Safe Drinking Water Act (SDWA) regulates drinking water in the United States and gives the EPA the power to enforce National Primary Drinking Water Regulations (NPDWR) for specific contaminants and to determine the legally enforceable limit (MCL). There are seventy-eight substances with a federal MCL, but nothing has been added to the list since the SDWA was amended in 1996 (Fedinick et al. 2017).

\section{i. EPA Rulemaking}

Section 1412 of the SDWA outlines three phases to establish a Federal MCL for a new contaminant: 1) Identification, 2) Evaluation and 3) Regulation. For TCP, the EPA collected national occurrence data from 2013-2015 but since then the agency has not taken any further formal regulatory steps forward. The EPA also has yet to publish a national map showing where groundwater tests positive for TCP. During the second phase, evaluation, the EPA uses three criteria to decide whether they should start to develop a new NPDWR: health risk, high occurrence, and the reduction of risk. If the EPA Administrator determines that those criteria are met, it proceeds with regulation (U.S. SDWA, Section 1412, 1996). Multiple studies show TCP's potential to cause cancer and UCMR monitoring has been available for six years showing contamination in over a quarter of U.S. states and Puerto Rico (U.S. EPA 2017c). GAC, California and Hawaii's BAT for TCP, is a well-known and tested technology which can lower TCP levels to the detection limit (Babcock et al. 2018). It is past time for the EPA to move TCP to the third phase: regulation.

\section{ii. State Regulations}

In lieu of a federal MCL some states have established their own MCLs to protect consumers from TCP. Hawaii, New Jersey, and California have set MCLs at 600 ppt, 30 ppt and 5 ppt respectively (Torralba-Sanchez et al. 2020). California requires public wells above the limit to: provide an approved treatment such as GAC; discontinue use of the well; purchase water from another utility; consolidate with other water systems; or dilute water to below the MCL (SWRCB 2018). California's strict regulations should be a blueprint for the EPA to follow.

\section{Policy Options}

There are three policy options for the EPA's consideration. Option A presents the least risk for U.S. citizens and the highest potential treatment costs whereas option $\mathrm{C}$ has the greatest health risk. A federal TCP regulation may mean that some water systems may not have to install a new treatment system as one may already be in place for DBCP, a common co-contaminate with TCP.

\section{i. Option A}

The EPA should adopt the lowest detection limit (5 ppt) as the MCL for TCP. This provides the highest level of protection for citizens who depend on groundwater for drinking water.

\section{ii. Option $B$}

Adopt a higher MCL for TCP like New Jersey and Hawaii (30-600 ppt), which would mean lower implementation costs and an increase in the safety of drinking water sourced from groundwater in heavily impacted wells.

\section{iii. Option $C$}

Increase national testing especially in rural agricultural areas to better understand the distribution of TCP in groundwater supplies. Using this data, heavily impacted states should be advised to establish state level MCLs.

\section{Recommendation}

The EPA should adopt policy Option A to establish a federal MCL of 5 ppt for TCP. For chemicals thought to cause cancer the EPA sets the Maximum Contaminant Goal (MCLG) at zero; in other words, no amount of the substance in drinking water is considered acceptable. The MCL for TCP should be based on the lowest concentration that can currently be measured, which is 5 ppt. A federal MCL at the lowest possible detection limit, like that established 
in California, provides the most meaningful reduction in health risk for consumers (U.S. SDWA, Section 1412, 1996).

\section{References}

Babcock Jr, Roger W., Bryce K. Harada, Krishna M. Lamichhane, and Korey T. Tsubota. 2018. "Adsorption of 1, 2, 3-trichloropropane (TCP) to meet a MCL of 5 ppt." Environmental pollution 233: 910-915. https://doi.org/10.1016/i.envpol.2017.09.085

Balazs, Carolina L., and Isha Ray. 2014. "The drinking water disparities framework: on the origins and persistence of inequities in exposure." American journal of public health 104, no. 4: 603-611. https://doi.org/10.2105/AJPH.2013.301664

Book, Steven A., and David P. Spath. 2007. "Emerging contaminants in drinking water: a California perspective." Risk Assessment for Chemicals in Drinking Water: 303-313. https://doi.org/10.1002/9780470173381.ch1 $\underline{2}$

Burow, Karen R., Walter D. Floyd, and Matthew K. Landon. 2019. "Factors affecting 1, 2, 3-trichloropropane contamination in groundwater in California." Science of the Total Environment 672: 324-334. https://doi.org/10.1016/i.scitotenv.2019.03.4 $\underline{20}$

California Department of Food and Agriculture (CDFA). 1970-84. Annual Pesticide Use Reports 1970-1984. California State Library Government Publications.

Damania, Richard, Sébastien Desbureaux, Aude-Sophie Rodella, Jason Russ, Esha Zaveri. 2019. Quality Unknown: The Invisible Water Crisis. Washington, DC: World Bank. https://openknowledge.worldbank.org/handle $\angle 10986 / 32245$

Fedinick, Kristi Pullen, and Mae Wu. 2017. "Threats on Tap: Widespread Violations Highlight." The Natural Resources Defense Council. http://ktvk.images.worldnow.com/library/d3 72ccb7-a023-4177-a362-75f7f05e918b.pdf

Hauptman, Hope, and Colleen C. Naughton. 2021. "Legacy 1, 2, 3-trichloropropane contamination: a systematic review of treatments." Journal of Water, Sanitation and Hygiene for Development. https://doi.org/10.2166/washdev.2021.006

Irwin, Richard D., Joseph K. Haseman, and Scot L. Eustis. 1995. "1, 2, 3-Trichloropropane: a multisite carcinogen in rats and mice." Fundamental and Applied Toxicology 25, no. 2: 241-252. https://doi.org/10.1006/faat.1995.1060

Kielhorn, Janet, G. Konnecker, Charles Pohlenz-Michel, S. Schmidt, Inge Mangelsdorf, and World Health Organization. $2003 . \quad 1$, 2, 3-Trichloropropane. World Health Organization. https://apps.who.int/iris/bitstream/handle/1 0665/42641/9241530561.pdf

Klein, Kerry. 2018. "To Pay For 1,2,3-TCP Cleanup, A Viable Strategy: Sue." Valley Public Radio, August $14,2018$. https://www.kvpr.org/post/pay-123-tcp-clean up-viable-strategy-sue

La, David K., Robert Schoonhoven, Norio Ito, and James A. Swenberg. 1996. "The effects of exposure route on DNA adduct formation and cellular proliferation by $1, \quad 2$, 3-trichloropropane." Toxicology and applied pharmacology 140, no. 1: 108-114. https://doi.org/10.1006/taap.1996.0203

National Toxicology Program (NTP). 1993. "Toxicology and carcinogenesis studies of 1,2 , 3-trichloropropane (CAS no 96-18-4) in F344-N rats and B6C3F1 mice (gavage studies)." US Department of Health and Human Services: Public Health Service: National Institutes of Health. https://pubmed.ncbi.nlm.nih.gov/12692652/

North, Mike. 2011. "Livingston Awarded \$9 Million Settlement." Merced Sun Star, September 20, 2011. https://www.mercedsunstar.com/news/local/ article3260829.html

Schaider, Laurel A., Lucien Swetschinski, Christopher Campbell, and Ruthann A. Rudel. 2019. "Environmental justice and drinking water quality: are there socioeconomic disparities in nitrate levels in US drinking water?" Environmental Health: 18, no. 1: 1-15. https://doi.org/10.1186/s12940-018-0442-6 
Schlesinger, Paul. 2019. "City of Atwater Wins \$63 Million from Lawsuit with Shell Oil Co. over Tainted Water." YourCentralValley.com, August 30 , 2019. https://www.yourcentralvalley.com/news/top -stories/city-of-atwater-wins-63-million-fromlawsuit-with-shell-oil-co-over-tainted-water/.

State Water Resources Control Board (SWRCB). 2018. "1,2,3-Trichloropropane (1,2,3-TCP) Maximum Contaminant Level (MCL)." Div. Drinking Water Branch.

https://www.waterboards.ca.gov/drinking wa ter/certlic/drinkingwater/documents/123-tcp /123tcp utility training.pdf

Tardiff, Robert G., and M. Leigh Carson. 2010. "Derivation of a reference dose and drinking water equivalent level for 1, 2, 3-trichloropropane." Food and chemical toxicology 48, no. 6: 1488-1510. https://doi.org/10.1016/i.fct.2010.03.016

Teitelbaum, Daniel Thau. 1999. "The toxicology of 1 , 2-dibromo-3-chloropropane (DBCP): a brief review." International Journal of Occupational and Environmental Health 5, no. 2: 122-126. https://doi.org/10.1179/oeh.1999.5.2.122

Torralba-Sanchez, Tifany L., Eric J. Bylaska, Alexandra J. Salter-Blanc, Douglas E. Meisenheimer, Molly A. Lyon, and Paul G. Tratnyek. 2020. "Reduction of 1, 2, 3-trichloropropane (TCP): pathways and mechanisms from computational chemistry calculations." Environmental Science: Processes

\& Impacts 22, no. 3: 606-616. https://doi.org/10.1039/C9EM00557A

U.S. Environmental Protection Agency (EPA). 2009. "Toxicological review of 1,2,3-trichloropropane In Support of Summary Information on the Integrated Risk Information System (IRIS)." https://cfpub.epa.gov/ncea/iris/iris documen ts/documents/toxreviews/0200tr.pdf

U.S. Environmental Protection Agency (EPA). 2012. "Revisions to the Unregulated Contaminant Monitoring Regulation (UCMR 3) for Public Water Systems." https://www.govinfo.gov/content/pkg/FR-20 12-05-02/pdf/2012-9978.pdf

U.S. Environmental Protection Agency (EPA). 2017a. 'Technical Fact Sheet - 1,2,3-Trichloropropane (TCP)."

https://www.epa.gov/fedfac/technical-fact-sh eet-123-trichloropropane-tcp
U.S. Environmental Protection Agency (EPA). 2017b. "Data Summary of The Third Unregulated Contaminant Monitoring Rule." Accessed June 30 , 2021. https://www.epa.gov/dwucmr/data-summary -third-unregulated-contaminant-monitoring-ru $\underline{\text { le }}$

U.S. Environmental Protection Agency (EPA). 2017c. "Occurrence Data for the Unregulated Contaminant Monitoring Rule 2013-2015." https://www.epa.gov/dwucmr/occurrence-dat a-unregulated-contaminant-monitoring-rule\#3

U.S. Environmental Protection Agency (EPA). 2002. "National Primary Drinking Water Regulations; Announcement of the Results of EPA's Review of Existing Drinking Water Standards and Request for Public Comment 2002." Accessed June 30, 2021. https://www.federalregister.gov/documents/2 002/04/17/02-9154/national-primary-drinki ng-water-regulations-announcement-of-the-re sults-of-epas-review-of-existing

U.S. Environmental Protection Agency (EPA). n.d. "Understanding how EPA develops new drinking water regulations." Accessed June 30, 2021.

https://www.epa.gov/sdwa/how-epa-regulate s-drinking-water-contaminants

U.S. Safe Drinking Water Act (SDWA). 1996. Committee on Environment and Public Works. U.S. Government Printing Office. Accessed June 30, 2021.

https://www.govinfo.gov/content/pkg/CPRT-1 06SPRT67528/pdf/CPRT-106SPRT67528.pdf

Villeneuve, D. C., I. Chu, V. E. Secours, M. G. Cote, G. L. Plaa, and V. E. Valli. 1985. "Results of a 90-day toxicity study on 1, 2, 3-and 1, 1, 2-trichloropropane administered via the drinking water." Science of The Total Environment 47: 421-426. https://doi.org/10.1016/0048-9697(85)9034 $\underline{6-8}$

Walpole, Sarah Catherine, David Prieto-Merino, Phil Edwards, John Cleland, Gretchen Stevens, and Ian Roberts. 2012. "The weight of nations: an estimation of adult human biomass." $B M C$ Public Health 12, no. 1: 1-6. https://doi.org/10.1186/1471-2458-12-43

B. Hope Hauptman is a third-year graduate student in Environmental Systems at the University of California Merced. Key objectives of her research are to understand historical land use patterns and 
1,2,3-trichloropropane (TCP) contamination in California's Central Valley and to address social equity issues surrounding drinking water quality globally. Ms. Hauptman recently published a systematic review of drinking water treatment methods for 1,2,3-trichloropropane (TCP) in the Journal Water Sanitation and Hygiene for Development. She previously taught high school science in the San Francisco Bay Area for over ten years and was a Volunteer Science Educator in the U.S. Peace Corps in Kenya. She earned a B.S. in Microbiology and Molecular Genetics (MMG) at University of California, Los Angeles and an MS in Instructional Science and Technology from California State University Monterey Bay.

Dr. Colleen C. Naughton is an Assistant Professor in Civil and Environmental Engineering at the University of California Merced. Her lab co-designs sustainable Food-Energy-Water Systems for and with the UnderServed (FEWS-US) nationally and globally. The FEWS-US lab develops and utilizes methods in Life Cycle Assessment (LCA), Geographic Information Systems (GIS), integration of anthropology and engineering, and science policy. Prior to joining UC Merced, Dr. Naughton was an American Association for the Advancement of Science (AAAS) Science and Technology Policy Fellow in Washington D.C. She is a Returned Peace Corps Water, Sanitation, and Hygiene Volunteer from Mali, West Africa, and University of South Florida (M.S. and PhD.), and Purdue (B.S.) alumni in Civil Engineering.

\section{Acknowledgements}

The authors would like to acknowledge the contributions of Dr. Paul Tratnyek, professor at the Oregon Health \& Science University School of Public Health, for providing background materials and sharing his knowledge of TCP contamination with the co-authors and to California State librarian Bradly Seybold for supplying the Pesticide Use Reports. 